\title{
Constraint Analysis in Production and Marketing of Katarni Rice in Bihar, India
}

\author{
Ramnath K. Ray ${ }^{1}$, Mukesh K. Wadhwani ${ }^{1 *}$, M. Rahaman ${ }^{1}$, \\ Makesh Kumar ${ }^{2}$ and Puja Sinha ${ }^{1}$ \\ ${ }^{1}$ Department of Agricultural Economics, Bihar Agricultural University, Sabour, \\ Bhagalpur - 813210 , India \\ ${ }^{2}$ Department of Plant Breeding and Genetics, Bihar Agricultural University, Sabour, \\ Bhagalpur - 813 210, India \\ *Corresponding author
}

\section{A B S T R A C T}

Bhagalpur district of Bihar has been a traditional aromatic rice growing area, where the varieties, like Katarni, Tulsi Manjari, Badshahbhog, Br-9 and Br-10 are most common. This variety has been given Geographical Indication (GI) due to its unique and special quality trait which develops only in its GI territory area. Despite its uniqueness katarni rice is facing the threat of extinction, mainly due to declining irrigation facility, adoption of other high yielding rice varieties and adulteration by traders of non- aromatic rice grains with katarni with the profit motto. In the light of above context the present investigation was undertaken to study the constraints in production and marketing of this precious rice variety. The Garrett's Ranking Technique was used for constraints analysis. Agro-biological constraints included low rainfall (Garrett Score $=65.48$ ), for poor soil condition and high infestation of pest was expressed. Whereas technological constraints included non availability of improved seeds of katarni rice (Garrett score $=54.27$ ) followed by poor quality of seed. Non availability fertilizer in the market in time was another aspect of technological constraint. It was found that irrigation was major economic constraints faced by sample farmers in production of katarni rice followed by its availability and charges on the basis of Garrett score of 55.70, 53.80 and 40.50 respectively. The marketing constrains included place of marketing, mode of transport, market agency and mode of sale of katarni paddy/rice. Among place of marketing village market was the most important constrain on all category of frams. The majority of sample farmer sold their produce in village market (Ranked $1^{\text {st }}$ with Garrett score 66.67) followed by at farm (Ranked $2^{\text {nd }}$ with G. score 33.33). The cash as well as credit both mode of sale was followed by the farmers in marketing of katarni rice in study area. The study suggests there is need for intensification of transfer of production technology particularly assured availability of quality seed and remunerative price to the produces. This will not only help in protection of katarni rice, pride of Bihar and enhancing the income of the farmers. The katarni rice growers may be encouraged to form a Producer Company to harvest the benefits of various Government programmes.

\section{Introduction}

Rice is one of the major food crops of Bihar, which plays a critical role in the food security. It is cultivated in an area of $3.3 \mathrm{~m}$. ha with production of 8.09 m.t. (2017-18). The average yield of rice in Bihar is $2447 \mathrm{~kg} / \mathrm{ha}$ which is lower than the national average of $2550 \mathrm{~kg} / \mathrm{ha}$. Though a number of local aromatic rice varieties are also grown all over the state, they are mainly concentrated in Bhagalpur and Magadh divisions. Bhagalpur has been a traditional aromatic rice growing area, where the varieties, like Katarni, Tulsi Manjari, Badshahbhog, Br-9 and $\mathrm{Br}-10$ are most common. In Magadh region of state varieties like Karibank, Marueya, Mehijawain, Shyamjira, Tulsiphool, Sonachur and Shah Pasand are cultivated. Their yield vary from 2.0 to $2.5 \mathrm{t} / \mathrm{ha}$. In general the aromatic local 
rice varieties which have yield potential from 20-25 q/ha, are tall and have characteristic short grain. Many of them are highly susceptible to various insect-pests and diseases like stem borer, bacterial blight and blast. Since they have excellent cooking quality and aroma, they are mostly grown by farmers on small scale. All land race of aromatic type grown in Bihar have fine but short grains and consequently fetch low price and export values. It has led to constant declines in their area.

"Katarni Rice" is the ceremonial fine rice of Bihar. It is famous for its aromatic flavour, taste, palatability and chura (beaten rice) making qualities. It is being produced in districts of Bhagalpur, Banka and Munger. The unique aroma in the Katarni grain comes only when it is grown in few blocks namely Jagdishpur, Sultanganj in Bhagalpur, Amarpur, Rajaun, Barahat in Bnka and Tarapur and Asharganj in Munger. Recently Katarni Rice has been given Geographical Indication (GI) tag br the Geographical Indications Registry Office, Chennai due to its unique and special quality traits which develops only in its GI territory area. Despite its uniqueness katarni rice is facing the threat of extinction. Since 1991-92, there has been significant decrease in the area of katarni rice cultivation, mainly due to declining irrigation facility, adoption of other high yielding rice varieties and adulteration by traders of nonaromatic rice grains with katarni with the profit motto.

In view of the lower yield and other technoeconomic constraints there is an urgent need to protect this precious rice variety from extinction and safeguard various stakeholders associated with this crop. In the light of above context the present investigation was undertaken to study the constraints in production and marketing of this precious rice variety. This study has been planned with main aimed to identifying the major constrains faced by the farmers.

\section{Materials and Methods}

\section{Sampling Procedure}

The Multi Stage Sampling Technique was used in selection of sample farmers. The Bhagalpur district, being the major katarni rice growing district in the state was selected purposively. At $2^{\text {nd }}$ stage, Jagdishpur block was selected on the basis of highest area under katarni rice in the district. Further at $3^{\text {rd }}$ stage six katarni rice growing villages, 3 from each of two clusters of villages of Jagdishpur block were selected randomly. Finally a sample of 90 katarni rice growers (15 from each village) was selected. The sample consisted of farmers; i.e. 15 Marginal (< 1ha), 40 Small (12 ha.), 35 Medium (> 2 ha) were selected randomly by simple random sampling without replacement (SRSWOR) technique. The primary data were collected from sample katarni rice growers for the agriculture year 2017- 2018 through personal interview. The operational land holding size ranged between $0.75,1.31$, and 2.78 ha among three categories of sample farms with overall mean as 1.79 ha.

\section{Analytical Technique}

Initially production and marketing constraints were listed separately. Further the Garrett's Ranking Technique was used for constraints analysis. In this method, respondents were asked to rank the specific problems faced by them according to their own perception. The assigned rank was converted into percentage position which is subsequently transferred into Garrett score using Garrett's table given by Garret and Wood worth (1969). For each constraint, scores of individual respondents were added together and then divided by total number of respondent from whom scores were gathered. Thus, mean score for each constraint 
was Ranked by arranging them in descending order.

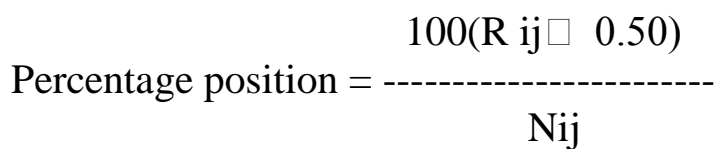

Where, $\mathrm{R}$ ij= Rank given for the ith item by the $\mathrm{jth}$ individual and

$\mathrm{N} \mathrm{j}=$ Number of items Ranked by the jth individual

\section{Results and Discussion}

\section{Constraints in production of Katarni rice}

\section{Agro-Biological constraints}

Agro-biological constraints faced by different categories of sample katarni rice growers are presented in table 1. It was found that majority of the farmers considered low rainfall; i.e. Ranked $1^{\text {st }}$ (65.48 score) most important constraints followed by Ranked $2^{\text {nd }}(51.82$ score) for poor soil condition, high infestation of pest was expressed Ranked 3rdwith Garrett score (46.62) and Natural calamities was considered Ranked $4^{\text {th }} \quad(35.81$ score $)$ respectively.

\section{Technological Constraints}

The constraints on uses of technology faced by sample Katarni rice growers are presented in table 2. Non availability of improved seeds of katarni rice was considered as major technological constraints (Ranked $1^{\text {st }}$ with Garrett score of 54.27) followed by poor quality of seed (Ranked $2^{\text {nd }}$ with 52.91 score), high price (Ranked 3rdwith 44.39 score) by the sample farmers. Non availability fertilizer in the market in time was another aspect of technological constraint and it was found that availability of urea Ranked $1^{\text {st }}$ (55.63 score) followed by DAP (Ranked $2^{\text {nd }}$ with 52.71 score), mix fertilizer (Ranked $3^{\text {rd }}$ (52.43 score) and MoP (Ranked $4^{\text {th }}$ with 40.22 score). Among plant protection constraints incidences of diseases \& pest, availability of chemicals and their prices were studied. The results showed that sample farmers considered incidences of pests \& diseases as most important constraint (Ranked $1^{\text {st }}$ with 62.52 score) followed by high price of chemicals (Ranked $2^{\text {nd }}$ with 53.17 score), nonavailability of chemical Ranked $3^{\text {rd }}(47.17$ score) while other constraints faced by the farmers was least important (Ranked $4^{\text {th }}$ with 41.89 score). The same trend was observed under different categories of farmers also.

\section{Economic Constrains}

Under the post Green Revolution era the crop production became irrigation and labour responsive. Therefore these two were studied and the results are presented in table 3 and 4 respectively.

It was found that source of irrigation was major economic constraints faced by sample farmers in production of katarni rice followed by availability of water and charges on the basis of Garrett score of 55.70, 53.80 and 40.50 respectively (table 3 ).

The results pertaining to labour constraints faced sample farmers in production of katarni rice has been presented in table 4 . The table reveals that high cost of labour charges at the time of transplanting and harvesting was considered as most important constraints followed by not availability of labour by the sample farmers.

In terms of category -wise scenario, the marginal farmers considered availability of labour as more important constraint as compared to its availability, which is obvious because they perform most of the farming activities by themselves except transplanting and harvesting. 
Table.1 Agro-Biological constraints faced by sample farmers in production of Katarni rice

\begin{tabular}{|c|c|c|c|c|c|c|c|c|}
\hline \multirow{3}{*}{$\begin{array}{l}\text { Agro-Biological } \\
\text { constraints }\end{array}$} & \multicolumn{6}{|c|}{ Category of sample farmer } & \multirow{2}{*}{\multicolumn{2}{|c|}{ Overall $(n=90)$}} \\
\hline & \multicolumn{2}{|c|}{ Marginal $(n 1=15)$} & \multicolumn{2}{|c|}{ Small $(n 2=40)$} & \multicolumn{2}{|c|}{ Medium (n3=35) } & & \\
\hline & $\begin{array}{l}\text { Garrett } \\
\text { score }\end{array}$ & Rank & $\begin{array}{l}\text { Garrett } \\
\text { score }\end{array}$ & Rank & $\begin{array}{l}\text { Garrett } \\
\text { score }\end{array}$ & Rank & $\begin{array}{l}\text { Garrett } \\
\text { score }\end{array}$ & Rank \\
\hline Rainfall & 69.00 & I & 66.95 & I & 62.29 & I & 65.48 & I \\
\hline Soil & 51.53 & II & 53.33 & II & 50.23 & II & 51.82 & II \\
\hline $\begin{array}{l}\text { Infestation of } \\
\text { pest \& disease }\end{array}$ & 42.47 & III & 45.35 & III & 49.86 & III & 46.62 & III \\
\hline $\begin{array}{l}\text { Natural } \\
\text { Calamities }\end{array}$ & 31.93 & IV & 33.83 & IV & 39.74 & IV & 35.81 & IV \\
\hline
\end{tabular}

Table.2 Technological Constraints faced by sample farmers in production of Katarni rice

\begin{tabular}{|c|c|c|c|c|c|c|c|c|c|}
\hline \multirow[t]{3}{*}{ S.N. } & \multirow{3}{*}{$\begin{array}{l}\text { Technological } \\
\text { constraints }\end{array}$} & \multicolumn{8}{|c|}{ Category of farmer } \\
\hline & & \multicolumn{2}{|c|}{ Marginal(n1=15) } & \multicolumn{2}{|c|}{ Small $(\mathrm{n} 2=40)$} & \multicolumn{2}{|c|}{ Medium (n3=35) } & \multicolumn{2}{|c|}{ Overall $(n=90)$} \\
\hline & & $\begin{array}{l}\text { Garrett } \\
\text { score }\end{array}$ & Rank & $\begin{array}{l}\text { Garrett } \\
\text { score }\end{array}$ & Rank & $\begin{array}{l}\text { Garrett } \\
\text { score }\end{array}$ & Rank & $\begin{array}{l}\text { Garrett } \\
\text { score }\end{array}$ & Rank \\
\hline A. & \multicolumn{9}{|l|}{ Seed } \\
\hline i. & Quantity & 51.27 & II & 54.10 & II & 55.74 & I & 54.27 & I \\
\hline ii. & Quality & 54.07 & I & 54.50 & I & 51.06 & II & 52.91 & II \\
\hline iii. & Price & 45.87 & IV & 44.53 & IV & 43.60 & III & 44.39 & IV \\
\hline iv. & Other & 49.80 & III & 47.88 & III & 50.60 & IV & 49.43 & III \\
\hline B. & \multicolumn{9}{|c|}{ Fertilizer: Non- availability } \\
\hline i. & Urea & 55.73 & II & 53.80 & II & 57.69 & I & 55.63 & I \\
\hline ii. & $\begin{array}{l}\text { Di Ammonium } \\
\text { Phosphate }\end{array}$ & 62.27 & I & 52.68 & III & 48.66 & III & 52.71 & II \\
\hline iii. & Murate of Potash & 41.53 & IV & 40.43 & IV & 39.43 & IV & 40.22 & IV \\
\hline iv. & Mix-fertilizer & 42.33 & III & 54.10 & I & 54.86 & II & 52.43 & III \\
\hline C. & \multicolumn{9}{|l|}{ Plant Protection } \\
\hline i. & Diseases \&Pest & 61.00 & I & 65.63 & I & 59.57 & I & 62.50 & I \\
\hline ii. & $\begin{array}{l}\text { Availability of } \\
\text { chemical }\end{array}$ & 43.00 & IV & 45.75 & III & 50.57 & III & 47.17 & III \\
\hline iii. & Price & 54.33 & II & 51.75 & II & 54.29 & II & 53.17 & II \\
\hline iv. & Any others & 46.67 & III & 39.38 & IV & 42.71 & IV & 41.89 & IV \\
\hline
\end{tabular}

Table.3 Constraints faced in irrigation by sample farmers in production of Katarni rice

\begin{tabular}{|c|c|c|c|c|c|c|c|c|}
\hline \multirow[t]{3}{*}{ Variable } & \multicolumn{6}{|c|}{ Category of farmer } & \multirow{2}{*}{\multicolumn{2}{|c|}{ overall $(n=90)$}} \\
\hline & \multicolumn{2}{|c|}{ Marginal $(\mathrm{n} 1=15)$} & \multicolumn{2}{|c|}{ Small $(\mathrm{n} 2=40)$} & \multicolumn{2}{|c|}{ Medium $(n 3=35)$} & & \\
\hline & $\begin{array}{l}\text { Garrett } \\
\text { score }\end{array}$ & Rank & $\begin{array}{l}\text { Garrett } \\
\text { score }\end{array}$ & Rank & $\begin{array}{l}\text { Garrett } \\
\text { score }\end{array}$ & Rank & $\begin{array}{l}\text { Garrett } \\
\text { score }\end{array}$ & Rank \\
\hline $\begin{array}{l}\text { Source } \\
\text { (Govt./Pvt/Co-Op) }\end{array}$ & 57.70 & I & 57.13 & I & 53.26 & I & 55.70 & I \\
\hline Availability & 57.60 & II & 53.80 & II & 52.17 & II & 53.80 & II \\
\hline Charges & 34.80 & III & 39.08 & III & 44.57 & III & 40.50 & III \\
\hline
\end{tabular}


Table.4 Constraints faced on labour by sample farmers in production of Katarni rice

\begin{tabular}{|c|c|c|c|c|c|c|c|c|}
\hline \multirow[t]{3}{*}{ Variable } & \multicolumn{6}{|c|}{ Category of farmer } & \multirow{2}{*}{\multicolumn{2}{|c|}{ overall $(n=90)$}} \\
\hline & \multicolumn{2}{|c|}{ Marginal $\left(n_{1}=15\right)$} & \multicolumn{2}{|c|}{ Small $\left(\mathrm{n}_{2}=40\right)$} & \multicolumn{2}{|c|}{ Medium $\left(\mathrm{n}_{3}=35\right)$} & & \\
\hline & $\begin{array}{l}\text { Garrett } \\
\text { score }\end{array}$ & Rank & $\begin{array}{l}\text { Garrett } \\
\text { score }\end{array}$ & Rank & $\begin{array}{l}\text { Garrett } \\
\text { score }\end{array}$ & Rank & $\begin{array}{l}\text { Garrett } \\
\text { score }\end{array}$ & $\underset{\mathbf{k}}{\operatorname{Ran}}$ \\
\hline $\begin{array}{l}\text { Availability of } \\
\text { labour }\end{array}$ & 50.87 & I & 44.80 & II & 41.46 & II & 44.51 & II \\
\hline $\begin{array}{l}\text { High labour } \\
\text { wages }\end{array}$ & 49.13 & II & 55.20 & I & 58.54 & I & 55.49 & I \\
\hline
\end{tabular}

Table.5 Constraints faced by sample farmers in marketing of Katarni rice

\begin{tabular}{|c|c|c|c|c|c|c|c|c|}
\hline \multirow{3}{*}{ Variable } & \multicolumn{6}{|c|}{ Category of farmer } & \multirow{2}{*}{\multicolumn{2}{|c|}{$\begin{array}{c}\text { Overall } \\
(n=90)\end{array}$}} \\
\hline & \multicolumn{2}{|c|}{$\begin{array}{l}\text { Marginal } \\
(\mathrm{n} 1=15)\end{array}$} & \multicolumn{2}{|c|}{ Small $(\mathrm{n} 2=40)$} & \multicolumn{2}{|c|}{ Medium $(n 3=35)$} & & \\
\hline & $\begin{array}{l}\text { Garrett } \\
\text { score }\end{array}$ & Rank & $\begin{array}{l}\text { Garrett } \\
\text { score }\end{array}$ & Rank & $\begin{array}{l}\text { Garrett } \\
\text { score }\end{array}$ & Rank & $\begin{array}{l}\text { Garrett } \\
\text { score }\end{array}$ & Rank \\
\hline \multicolumn{9}{|c|}{ A. Place of marketing } \\
\hline Farm & 33.33 & II & 22.50 & II & 42.86 & II & 32.22 & II \\
\hline Village Market & 66.67 & I & 75.00 & I & 51.43 & I & 64.44 & I \\
\hline $\begin{array}{l}\text { District } \\
\text { Market }\end{array}$ & 0.00 & III & 0.00 & IV & 0.00 & IV & 0.00 & IV \\
\hline Other, specify & 0.00 & IV & 2.50 & III & 5.71 & III & 3.33 & III \\
\hline \multicolumn{9}{|c|}{ B. Mode of transport } \\
\hline Pickup & 21.00 & III & 22.50 & II & 20.00 & III & 24.44 & III \\
\hline Tractor(trolley & 40.00 & I & 32.50 & I & 45.71 & I & 35.56 & I \\
\hline truck & 23.00 & II & 17.50 & IV & 8.57 & IV & 14.44 & IV \\
\hline others & 17.00 & IV & 27.50 & III & 25.71 & II & 25.56 & II \\
\hline \multicolumn{9}{|c|}{ C. Market agency } \\
\hline $\begin{array}{l}\text { Village } \\
\text { Traders }\end{array}$ & 40.00 & I & 47.50 & I & 37.14 & I & 42.22 & I \\
\hline $\begin{array}{l}\text { Commission } \\
\text { agents }\end{array}$ & 26.67 & II & 7.50 & IV & 17.14 & III & 14.44 & IV \\
\hline Wholesalers & 13.33 & IV & 35.00 & II & 11.43 & $\mathrm{~V}$ & 22.22 & II \\
\hline Retailers & 20.00 & III & 10.00 & III & 34.29 & II & 21.11 & III \\
\hline \multicolumn{9}{|c|}{ D. Mode of sale } \\
\hline Cash & 40.00 & II & 17.50 & III & 15.29 & IV & 20.00 & II \\
\hline Credit & 7.67 & IV & 18.50 & II & 21.86 & III & 17.78 & III \\
\hline $\begin{array}{l}\text { Cash \& credit } \\
\text { both }\end{array}$ & 41.00 & I & 50.00 & I & 34.29 & I & 42.22 & $\mathbf{I}$ \\
\hline Forward trade & 12.33 & III & 11.50 & IV & 22.86 & II & 16.67 & IV \\
\hline
\end{tabular}


Constraints in marketing of Katarni rice grower

The major constraints faced by sample farmers in the marketing of Katarni rice were identified, and Garrett score based Ranked has been presented in the Table 5. The constrains included place of marketing, mode of transport, market agency and mode of sale of katarni paddy/rice. Among place of marketing village market was the most important constrain on all category of frams. The majority of sample farmers sold their produce in village market (Ranked $1^{\text {st }}$ with Garrett score 66.67) followed by at farm (Ranked $2^{\text {nd }}$ with G. score 33.33). The mode of transportation constraints were in the ascending order as tractor (Ranked 1st, 35.55) followed by truck (25.56) and pickup (21.00). The most important constraints related to marketing agency was Village Traders contractors (42.22) followed by Wholesaler (22.22) on overall basis. The cash as well as credit both mode of sale was followed by the farmers in marketing of katarni rice in study area.

It can be concluded from the foregoing investigation that major constraints faced by the farmers in production of katarni paddy/rice were low \& erratic rainfall, not available quality of seed, availability \& high price of fertilizers, high infestation of pest and disease. Availability of irrigation and labor availability at the time of transplanting and harvesting, the majority of the farmers were selling their produce in village market through Village Traders, to high transportation cost and long distance of market.

\section{Suggestion}

The findings suggests that there is need for intensification of transfer of production technology particularly assured availability of quality seed and remunerative price to the produces. This will not only help in protection of katarni rice, pride of Bihar and enhancing the income of the farmers. The katarni rice growers may be encouraged to form a Producer Company to harvest the benefits of various Government programmes.

\section{Acknowledgement}

The study is based on the M.Sc. (Ag) in Agricultural Economics Thesis of the first author submitted to the Bihar Agricultural University, Sabour, Bhagalpur towards partial fulfillment of M.Sc. (Ag) in Agricultural Economics Degree Programme under the supervision of first author.

The assistance provided in this investigation has duly been acknowledged.

\section{Abbreviations}

M.T. - Million Tonnes

GI - Geographical Indication

G. Score - Garrett score

M. ha - Million Hectare

$\mathrm{Kg} / \mathrm{ha}$ - Kilogram per hectare

T/ha - Tonnes per hectare

Q/ha - Quintal per hectare

Ha - Hectare

SRSWOR - Simple Random Sampling without Replacement Technique

DAP - Di-Ammonium Phosphate

MOP - Murate of Potash

\section{References}

Ahirwar RF, Sharma SK and Mahajan KC (2013) Indian Journal of Tropical Biodiversity, 21(1/2):65-72.

Hile RB, Kamble BT, Dattarkar SB and Darekar AS (2015) International Journal of Commerce and Business Management; 8(2): 174-183

Lakra N, Gauraha AK and Banafar KNS 
(2017) International Journal of Current Microbiology and Applied Sciences; (4): 108-115.

Maheriya, HN, Patel RC and Patel JB (2014)

Gujarat Journal of Extension Education; 25(1): 93-95.

Matto JM, Dar MA, Shah ZA, Beigh MA and Mir R (2017) International Journal of Current Microbiology and Applied Science; 6(12): 1206-1214.

Naing TAA, Kingsbury AJ, Buerkert A and Finckh MR, (2008) Journal of Agriculture and Rural Development in the Tropics and Subtropics; 109(2): 151-168.

Namdev GP, Shrivastava A and Awasthi PK
(2011) Indian Journal of Fundamental and Applied Life Sciences; 1(3): 141145.

Nirmala B and Muthuraman P (2009) Indian Research Journal of Extension Education; 9(1): 47-49.

Oinam T and Sudhakar B (2014) International Journal of Economic and Business Review, 7(2): 32-37.

Singh R, Singh GP, Raghuvanshi T, Singh C and Singh V (2017) the Pharma Innovation Journal; 6(12): 102-104.

Tiwari G, Singh P, Lodhi SK, Kumar M and Mishra A (2016) International Journal of Agriculture Sciences; 55(8): 29662968.

\section{How to cite this article:}

Ramnath K. Ray, Mukesh K. Wadhwani, M. Rahaman, Makesh Kumar and Puja Sinha. 2019. Constraint Analysis in Production and Marketing of Katarni Rice in Bihar, India. Int.J.Curr.Microbiol.App.Sci. 8(09): 2801- 2807.doi: https://doi.org/10.20546/ijcmas.2019.809.323 